\title{
Determinants of the Performance of Chinese Funded Projects in Kenya: A Case of "One Belt One Road" Initiative Project
}

\author{
Xia Anquan', James Maingi, ${ }^{2, *}$ \\ ${ }^{1}$ School of Business, Kenyatta University, Kenya \\ ${ }^{2}$ School of Economics, Kenyatta University, Kenya
}

Received September 1, 2019; Revised September 23, 2019; Accepted October 10, 2019

Copyright $\odot 2019$ by authors, all rights reserved. Authors agree that this article remains permanently open access under the terms of the Creative Commons Attribution License 4.0 International License

\begin{abstract}
Project performance entails the achievement of enhanced results from the organization, teams and individuals within agreed upon goals, objectives and standards. There is increased number of projects that have failed despite advance increase in adoption of best practice. The study sought to establish determinants of the performance of Chinese funded projects in Kenya, a case of "One Belt One Road" initiative projects. It concentrated on stakeholder involvement, infrastructure, change in legislation and loans. It focused on Standard Gauge Railway Project funded by the Chinese government as part of "One Belt One Road" initiative projects. The analysis of data was carried out by use of descriptive statistics and a multiple regression analysis. It established that the selected determinants to a significant extent influenced the performance of Chinese funded projects in Kenya. It concluded that the projects embraced stakeholder involvement to a significant extent, to a great extent project policy framework on technology, has influenced project performance, and the projects relied heavily on loans from the Chinese government. The study recommends that the project management should improve stakeholder involvement, consultation and also incorporate their feedback in the project implementation cycle to foster project performance.
\end{abstract}

Keywords Project Performance, One Belt One Road

\section{Introduction}

\subsection{Background of the Study}

The process of project implementation highlights a lot of challenges that organization/businesses need to deal with for it to be successful. It is very important to accept and own its project if it is to be implemented effectively (Das \& Ngacho, 2017). Any projects which are imposed on organization against their wills are likely to fail because the organization will not support them. A lot of policies have been put in place to ensure that there is full collaboration and partnership between the police force and the organization community in spotting and ameliorating crimes and law disobediences in the community to promote safe coexistence. This is based on the principle that the project community which is made up of people deserves to have an input and say on how their communities are improved (Njeri \& Were, 2017). This can only be achieved if they are involved in the project development from the initiation. Furthermore, the criminal actors live within the community and some community members could be having crucial information which may help bring to book the culprits and charge them according to the rule of law (Wang \& Law, 2017).

On the other hand, project performance management entails the achievement of enhanced results from the organization, teams and individuals within agreed upon goals, objectives and standards (Armstrong, 1994) According to Pinto and Slevin (1987), successful project implementation would entail timely implementation, within budget, with accountability and delivery of the desired results. According to Bainbridge (2011), there is a quality and accountability deficit in projects. He notes that it is evident, that field staffs working on projects are overwhelmed by many good practice commitments and standards they are to comply with including their own organizational policies and procedures. The role of staffs is important for organizational performance and successful partnerships (Keystone Partner Survey, 2011). There exists diversity of perceptions within the workforce. According to Lawrence, Zhang, Yan and Chen (2017), 
organizational decisions must balance between two opposing forces of differentiation and integration. Creativity and innovation would stem from the differences between various departments. The differences arise from the types of work performed, time frames of the work, people's skills knowledge and interpersonal orientations. Each of these functional structures (departments) must be coordinated by a departmental head for effectiveness and efficiency of operations. The absence of coordination in development projects may affect its performance (Awang \& Iranmanesh, 2017). It is notable culture for many project financiers to have an interest in knowing how their finances are applied. As a result, relationships are governed by contractual agreements signed at different levels. However organizations often experience disconnect between strategic plans developed at executive level and actual development projects. Organizational learning, knowledge sharing and training are important in project implementation (Chen, Zhang, Yan \& Jin, 2018).

Development projects involve considerable amounts of resources including financial. As financial resources become more competitive, their effective and efficient allocation is necessary to achieve planned objectives and goals which depict the success.Road project have been on the rise because the government alone could not much in ensuring that the transport sectors is effectively improved (Miruri \& Wanjohi, 2017). The Government therefore increased their support on investment especially road network. This has influenced increase of Chinese investors over the years increased because of has a mechanism to improve road network in Kenya. One of the projects funded the Chinese government include Mombasa Nairobi railways development through "One Belt One Road" initiative project. Its core objective is to ensure that there is free trade in countries that has joined the movement to basically improve the transport network.

\subsubsection{Project Performance}

According to Burke (2013), projects that are well managed always have the best data and information given by the area of residents. It becomes even easier to come up with good measures that govern the structures and principles which in the end lead to a smooth succession making the concerned stakeholders react quickly towards the succession of the project. Barthel and Isendahl (2013) confirms that many water projects engage financial expertise, community management and technical knowledge to help in developing the project within the set period of time. Involving the communities mostly provide support and give good information that the project developers will use when making decisions concerning the project before they can start developing it. The communities understand the area of residence much better and the strengths and weaknesses that they may be facing and they would what they would like the news the new project to consider (Dhimal, Aryal, Dhimal, Gautam,
Singh, Bhusal\&Kuch, 2014).

Projects have unique distinguishing characteristics from any other activities in the organization. Projects are normally temporary where they run only for specified period of time. Projects produce unique results meaning that the product or service at the end of the project should be some way different than the existing (Memon, Rahman, Abdullah \& Azis, 2014). Projects are also characterized by progressive elaboration due to uniqueness and greater uncertainty projects cannot be understood entirely at or before project start, and therefore planning and execution of projects is happening many times in separate steps or phases. As projects develop, project teams understand the steps to follow, deliverables and way of executing them much better (Minja, 2014).

\subsubsection{One Belt One Road Initiative Project}

This project is also referred to as the Belt and Road Initiative (BRI). Other person refers to it at the Silk Road Economic Belt and the 21st-century Maritime Silk Road. This project was initiated by the Chines government. Its main objective was to improve 152 countries infrastructure development and investment status of the countries involved. The countries were based in Europe, Middle East, Asia, African and Latin America. This project was announced by the President of the People's Republic of China on a special visit on Indonesia and Kazakhstan in 2013. This project was quickly promoted to Europe and Asia and promoted by different scholars. Cai,. (2017) referred to it as a connectivity system used to connect the countries. This project focused on member country infrastructure development, real estate development, contraction material development and railway and highway construction. The core value of this project was to address the infrastructure gap which is essential for economic growth across the member countries.

According to world pension council (WPC) report estimated that in Kenya alone required an estimated US $\$ 900$ billion to fund infrastructure development. This value could not be providing by the government. It takes combined effect in ensuring the projects are completed. This gap was therefore addressed by Chinese fund scheme known as One Belt One Road Initiative Project. The project leading group was advanced in in late 2014 and its leadership line-up publicized on February 1, 2015. The steering committee was supposed to report directly to state Republic of China together with other political heavy weights, investors and the government of Kenya. The Belt and Road Initiative is geographically structured along several land corridors.

\subsection{Statement of the Problem}

Project performance management entails the achievement of enhanced results from the organization, 
teams and individuals within agreed upon goals, objectives and standards. Organizational decisions must balance between two opposing forces of differentiation and integration. There is increased number of projects that have failed despite advance increase in adoption of best practice. Several studies on performance have revealed that in Kenya, performance is mixed despite numerous initiatives. A few studies have tried to account for the mixed performance especially in the context of multi-factor approach in understanding the effect of management on performance of projects.

Planning, availability of resources and natural factors are some of the elements that affect the timing of infrastructural projects. The implementation of project effectively and within budget would be influenced by the execution of project activities, accuracy of project financial forecasts and the subsequent forces of demand and supply on the project inputs. Stakeholders' satisfaction entails meeting their expectations in the implementation of the projects (Zahoor, Chan, Utama, Gao \& Memon, 2017). Financial accountabilities entail prudence and transparency in the utilization of projects for the purposes they are intended for these and other factors are thought by many to have led to growth of road project in Kenya.

Measures are often incorporated in the design of the projects to enhance project performance. Despite this, there would still be some deficiencies along the performance measures that would render projects unsuccessful. Given the failure rates of projects in relation to timeliness, within budget, desired results, stakeholder satisfaction and accountabilities, this research seeks to identify determinants of performance of development projects (Nguyen \& Watanabe, 2017).

On the other hand, project failure would entail lateness, cost ineffectiveness dissatisfied stakeholders and lack of accountabilities. The slow take up and failure of these development projects by the Community interest groups suggests that there exist some teething issues. While there are projects that have taken root and achieved sustainability, some have collapsed and given a poor picture in the planning management and implementation of the projects. These collapse, the officers hypothesize is influenced by a number of project factors. To what extent this is corroborated by empirical findings is questionable therefore the labor of this research to verify these factors. The study intended to establish determinants of the performance of Chinese funded projects in Kenya.

\subsection{Objectives of the Study}

\subsubsection{General Objectives}

The study seeks to establish determinants of the performance of Chinese funded projects in Kenya, a case of "One Belt One Road" initiative project

\subsubsection{Specific Objectives}

The study will be guided by the following specific objectives:

i) To establish the effect of stakeholder involvement on performance of One Belt One Road initiative project in Kenya.

ii) To determine the role of infrastructure on performance of One Belt One Road initiative project in Kenya.

iii) To find out the influence of change in legislation on performance of One Belt One Road initiative project in Kenya.

iv) To establish the effect of loans on performance of One Belt One Road initiative project in Kenya.

\subsection{Research Questions}

This study will be guided by the following questions:

i) What is the effect of stakeholder involvement on performance of One Belt One Road initiative project in Kenya?

ii) What is the role of infrastructure on performance of One Belt One Road initiative project in Kenya?

iii) What is the effect of change in legislation on performance of One Belt One Road initiative project in Kenya?

iv) To what extent do loans affect performance of One Belt One Road initiative project in Kenya?

\subsection{Significance of the Study}

The findings of this study would be significance to a number of stakeholders including: government of Kenya, project offices/ organization and future researchers. For the for Government of Kenya, the findings of this study would guide them in future implementation of infrastructure projects successfully because the factors identified in this study will inform their future actions.

The project financiers are increasingly becoming concerned on the effectiveness and efficiency in the utilization of funds by the recipients. The research findings will provide information that can be used to enhance the performance of development projects. It will significantly contribute to existing knowledge capable of enhancing effective and efficient utilization of projects funds by implementing partners.

The results of this study would also be significant to future researchers and scholars in that it would act as an empirical source of material besides suggesting areas where they can focus their studies. This study therefore would contribute to the growth of empirical literature besides providing focus for future studies and the study would also be relevant to the project offices/ organization at large because the study will find factors that can promote the successful performance of performance of project to ensure that it achieves its mandate. 


\subsection{Scope of the Study}

This study will focus on determinants of the performance of Chinese funded projects in Kenya taking a close look at One Belt One Road initiative project. The study will concentrated on Stakeholder Involvement, Infrastructure, Change in Legislation and Loans and how they affect performance of Chinese funded projects. The study will focus on Standard Gauge Railway Project funded by the Chinese government as part of One Belt One Road initiative project. The targeted population will entails SGR management staff which will include project coordinator, project manager, government representative from Kenya and china, operating staff and community representative. This study will be conducted between April and May 2019.

\subsection{Limitation of the Study}

The study is limited to determinants of the performance of Chinese funded projects in Kenya taking a close look at One Belt One Road initiative project. A large research would be the best for findings to be comprehensive. The respondents however, will be afraid of giving information that is serious because they felt they are exposing the firm's weakness or they felt they were victimized. Moreover, the respondents will be assured of the handling of the information that they would have given with utmost confidentiality. On the other hand, financial problems by the researcher in terms of photocopying, cost on transport, secretarial services etc.

\section{Literature Review}

\subsection{Introduction}

This chapter put its focus on the theories that are used in the study. It provides a summary of the information from other philosophers that have done their research in the same field of the research. The chapter covers the model review, empirical review, and the conceptual framework.

\subsection{Theoretical Review}

The study will be based on contingency theory and theory of project management which are deemed to be the most suitable to understanding performance of "One Belt One Road" initiative project in Kenya.

\subsubsection{Contingency Theory}

The contingency theory was developed by Lawrence and Lorsch in (1967). The authors urge that the different environments place different requirements on organizations. Contingency theory can help understand core issues for implementing effective infrastructural project programs. They specifically emphasized on the environments marked by uncertainty and rapid change in market conditions and technological areas since these kinds of environments present different demands, both positive and negative, than relatively stable environments. While contingency theory has been greatly elaborated over years, the general orienting hypothesis of the theory suggests that design decisions depend on environmental conditions, meaning that organizations need to match their internal features to the demands of their environments in order to achieve the best adaptation.

In other words, driving force behind organizational change is the external environment, particularly the task environment with which an organization is confronted (Alexander, 2017). Steinbach, Holcomb, Holmes, Devers \& Cannella (2017) points out three assumptions that underline the contingency theory, which can be utilized to address the problems that are encountered in the implementation of government project programs: There is no one best way to organize; any way of organizing is not equally effective and the best way to organize depends on the nature of the environment to which the organization relates. This theory is relevant to the study in that it explains the forces behind project performance and the requirement that this project need to deal with in terms of change in environment status which include change of legislation.

\subsubsection{Theory of Project Management}

Project management, and indeed all production, has three kinds of goal. Firstly, the goal of getting intended products produced in general. Secondly, there are internal goals, such as cost minimization and level of utilization. Thirdly, there are external goals related to the needs of the customer, like quality, dependability and flexibility. An explicit theory of project management would serve various functions. In prior research, the following roles of a theory have been pinpointed (Cicmil, Cooke-Davies, Crawford \& Richardson, (2017): A theory provides an explanation of observed behavior, and contributes thus to understanding. A theory provides a prediction of future behavior. On the basis of the theory, tools for analyzing, designing and controlling can be built.

Regarding planning, the approach of management-as-organizing adds the idea of human activity as inherently situated (Papke-Shields \& Boyer-Wright, 2017). Thus, planning should also focus on structuring the environment to contribute to purposeful acting. Concerning managerial execution, the language/action perspective, originated by Maylor \& Turner, 2017), conceptualizes two- way communication and commitment, instead of the mere one-way communication of the classical communication theory.

\subsection{Empirical Literature}

\subsubsection{Stakeholder Involvement and Performance}


Song, Yu, and Zhang, (2017) conducted a study on the effect of stakeholder satisfaction on and operational performance. The study main object was to assess the dimensions of involving stakeholder on performance of green procurement. The study used descriptive statistics to identify the effect of stakeholder's involvement. The main target of the study was 206 Chinese A-share companies. For effective analysis the study used secondary data that was collected from the repositories of the Chinese companies. This reports that was used were grown from Guotai Junan Securities Co., Ltd and Wind Information Co., Ltd. The study identified that the firms focuses on stakeholder's involvement on decision making which significantly influence performance of Chinese A-share companies. The study therefore concluded that stakeholder's involvement significantly influence productivity of different department of an organization.

Miruri and Wanjohi (2017) conducted a study on how Determinants of performance affect the operation of irrigation projects. The study was conducted on Nthawa irrigation project of Mbeere North Sub-county, Embu County. The study the variable was to determine the effect of management, community participation, resources adequacy, technology used and availability of sizable land for irrigation and how all this variable affect the peformance of public irrigation projects in Kenya. The study targeted registered members of Nthawa Irrigation Project. The study used census in the collection of this respondents and collected the primary data from them using structured questionnaire. The study identified that all the variables under study significantly affect performance of irrigation projects. The study therefore recommended that organization should formulate policies that allow and enhance full participation of the member or staff of the irrigation project.

Njeri and Were, (2017) conducted a study on the how determinants of project performance affect how the non-governmental organizations perform in Kenya. This study concentrated on Hand in Hand Eastern Africa. The study main purpose was to determine the effect of op management support, culture, schedule and project team commitment on the performance of NGOs. The targeted 304 respondents that comprises on management team of the NGOs. In defining the sample size the study used stratified random sampling and identified 105 respondents. Primary data was used which composed on structured questionnaire. The study revealed that project team commitment has a positive effect on project performance. To that effect the study recommended that the organization top management should delegate responsibilities to the project management teams and favorable policies incorporate to gear up the team toward project performance and motivate them to perform better.

García-Sánchez, García-Morales and Martín-Rojas (2018) conducted an analysis on how stakeholder integration capability, technological skills and environment affect performance of corporate entrepreneurship. The study focused on how these factors (technological skills, environment, absorptive capacity and stakeholder integration capability affect performance of corporate entrepreneurship. The study targeted 160 European technology firms. The hypothesis of the study was the entire variables have a positive relationship with performance of corporate entrepreneurship. The study used primary data collected from these firms and analyzed those using descriptive and inferential statistics. The study identified that the capacity of an organization to basically absorb new knowledge depend on the level of stakeholders involvement through skills development forums. The study also identified that stakeholders are required to be involved in firms general and constant updates, innovation of processes, production decision making and collaboration between parties to maintain their comparative advantage and performance.

\subsubsection{Infrastructure and Performance}

Skorobogatova and Kuzmina-Merlino (2017) studied the effect of infrastructure development on economic performance. This study was conducted in Latvia with special analysis on how infrastructure development on economic development of Latvia. The study described the importance of transport infrastructure on the importance state transport network. This study focused on the necessity for the development of the methodology of measuring the transport infrastructure performance, that should be applied systematically and that would be generally helpful to all responsible people making transportation-related decisions. The study identified that infrastructure development such as ICT and road network significantly influences economic performance. The study concluded that adequate infrastructure is a fundamental precondition for the country transport system.

Oyigbo and Ugwu (2017) conducted a study on how key performance indicators affect performance of road infrastructure. The study concentrated on the road infrastructure that been financed by public-private. The study identified that 11 performance indicators that has been used by Public-Private Partnerships (PPPs) in Nigeria. The study used primary data collected on the management of Public-Private Partnerships (PPPs). The data analysis will be done using both descriptive and inferential statistics. The study identified that a unit increase in road network size would significantly increase performance of Public-Private Partnerships. The study also identified that availability of infrastructure increases asset value,reduces user cost,reduces public sector administration costs, increases road usage, reduces travel time, reduces maintenance cost and reduces road accident. The study revealed that increased road network size is the most significant factor that affects most operation of the organizations.

Garrido, Gomez, de los Ángeles Baeza and Vassallo 
(2017) conducted a study on the effect of financial support that has been provided by Spanish government on enhancing economic performance. The study was conducted on Spanish road infrastructure projects. The study concentrated on the programs that were initiated by the European Union to how and to what extent that European support can influence performance of Public-Private Partnerships project. The study used both primary and secondary data that was drawn from government report and primary from structured questionnaire drawn from the management of Public-Private Partnerships project. The study indicated that financial assisted organization performed better economically as to compare the organization that has not been supported. The study concluded that there is significant correlation between performance and financial support.

Mauerhoefer, Strese and Brettel, (2017) conducted a study on the how information technology impacts performance of new product development. The study developed a conceptual model which is used to determine the how IT and non-IT organizational are affected by the availability of resources. The study was conducted on Germany IT firms thus the target population included the management teams of these firms. The study main intention was to address the limitation that associated with lack of technology and there effect on comparative advantage of the organization. The study identified that effectiveness new product development depend on the technology tools used. This tool has a positive significant on performance of the organization. The study also revealed that availability of effective tool cannot increase performance but the degree and the frequency at which the organization use it.

\subsubsection{Change in Legislation and Performance}

Perkins and Repper (2018) reviewed effect of mental health legislation on productivity change. The study was concentrated on how mental health effect productivity of IT firms in South Africa. The study used primary data for data collection. The data was then analyzed to determine the effect that the firm undergo when they have effectively dealt with any negativity that the organization employees might have. The study identified that firms that conduct forums to discuss the all matters that affect staff performance perform better than their counter parts that have not engaged their employees. The study therefore concluded that the method used by organization to control the mentality of the employees significantly influence how and to what level the staff are committed to their work.

Begen, Barnett, Payne, Gowland, Dunn Galvin and Lucas (2018) conducted a study on the effect that allergen information legislation have on the eating out pattern. The study was conducted in United kingdoms. This study focused on change in the eating out practices of consumers with food allergy as a result of change legislation. The main objective of the study was to investigate the impact that EU legislation have on the behaviors, experiences and attitudes of consumers with food allergy when eating out. The study used longitudinal research in its quest to determine the effect of information legislation on performance of food allergy firms. The study sampled 129 respondents from pre and post legislation and subjected to quantitative analyses. The finding identified that any improvement in allergen information provided and riced the awareness of food allergy. The findings also identified that this process also helped in communication between the staff, management and their customers. The study concluded that this process helped in improving judgment, and consistency in production processes for easy implementation of the organizational goals.

Cette, Lopez and Mairesse (2018) conducted a study on the how employment protection legislation can affect Capital and Skills Composition. The study main purpose is to identify the effect of employment protection legislation on four capital and three labor skill components. The study group data collected from Mexico ICT industry and used panel data to basically sample 18 industries. The data covered from 1988 to 2007. Secondary data was collected from 1988 to 2007. Descriptive and inferential statistics drawn from the organizations were used to verify the study. The study indicated that change employment protection legislation significantly impacts capital and labor performance. The findings confirms that providing strength to the employment protection legislation have a greater and negative effect on organizational change which breaks the risk of sharing market and divers of more regulation harmonization. Structural reforms should be formulated in labor flexibility, the process of weakening employment protection legislation.

De Leon and Pittock (2017) conducted a study on the integrating climate change adaptation and climate-related disaster risk-reduction policy in developing countries. This study was conducted in the Philippines. The study concentrated on disasters that are associated with costly catastrophic levels of destruction. The study looked at Key challenges norms and knowledge to determine the barriers that are associated with disaster management systems in developing countries. The findings indicated that failure of the organization to incorporate adequate and relevant actors, strategies; cost-effective financial structures and favorable financial structures affect tremendously performance of ICT firms. The study also identified that without adequate funds generation, community-level support and timely information provision then the firm will undergo difficulties in the decision-making structure with is the of legislation change. 


\subsubsection{Loans and Project Performance}

Dvouletý (2017) conducted a study on the how soft loans and credit guarantees affect the performance of organizations. This study was conducted in Czech Republic. The purpose of this study is to evaluate the effect of soft loans on the performance of Czech public programme START. The data was collected in 2007-2011. The data were collected from secondary sources and analyzed using counterfactual analysis to identify the changes in financial performance. The study concentrated on net profits, return on assets (ROA), and return on equity (ROE), sales, assets turnover, and debt ratio. The finding indicated that there is a positive impact of performance of organizational programme. The study also identified that the supported firms experience higher rate of return in terms of net profit, return on assets, and return on equity. The study therefore concluded that soft loans and credit guarantees significantly influence the performance of organization.

Eton, Mwosi, Mutesigensi and Ebong, (2017) conducted a study on the effect that credit financing have on the performance of SMEs. The study was conducted in Lira municipality, Uganda. The study determined the function/ role that credit financing have on performance of SMEs. The study used sample size of 120 respondents in the process of verifying the effect of credit financing on performance. Primary data was collected and analyzed. Both descriptive and inferential statistics drawn from the data coded. The study indicated that availability of financial assistance help them in access of very vital resources, increased their firms diversification and increased films production levels. The study recommended that Credit institutions. Should continue providing credit at affordable rates while endeavoring to train their clients on how to keep financial information, which is essential in assessing the borrower's credit worthiness. The study also recommended that the organization should also documents their transactions effectively and repay the loans to maintain credit worthiness

According to Kirsch and Rühmkorf (2017) study on the effect of sovereign borrowing, financial assistance and debt repudiation affect performance of organizations. The study investigated the effect of financial assistance on probability of default. The study used descriptive search design. The study constructed quantitative model to determine the credit structure and sovereign default which main function is to allow self-fulfilling expectations of default. The finding indicated that availability of resources significantly influence performance of organization. The study also noted that its availability reduces the number of loan defaulters because of elf-fulfilling runs by private investors. This also increases the overall debt causing overall increase in the probability of default.

Spencer, Samuel, Rosenstein, Reeder-Hayes, Manning, Sellers and Wheeler, (2018) conducted effect of financial burden and financial assistance resources on eradication and treatment of Oncology navigators' of cancer-related diseases. The study concentrated on a real time survey of oncology navigators' association conference. The study targeted oncology nurse navigators, social workers and lay navigators. The study used structure questionnaire which is composed of open-ended questions. The findings indicated that majority of the respondent that participated on the study were experiencing financial toxicity and only a small portion could access financial assistance. The most common barrier that was identified by study is complex/duplicative paperwork, lack of resources and lack of knowledge about resources. The study therefore concluded that Oncology navigators had higher burden of financial toxicity which is basically addressed by insufficient knowledge. It is therefore important for organizations to address financial burden to reduce and address the need community involved with an aim, of eliminating barriers. 


\subsection{Research Gap}

Table 1. Summary of Research Gap

\begin{tabular}{|c|c|c|c|}
\hline Author & Topic & Findings & Gap \\
\hline $\begin{array}{l}\text { Song, Yu, and Zhang, } \\
\text { (2017) }\end{array}$ & $\begin{array}{l}\text { Green procurement, } \\
\text { stakeholder satisfaction and } \\
\text { operational performance. }\end{array}$ & $\begin{array}{l}\text { the firms focuses on stakeholder's } \\
\text { involvement on decision making } \\
\text { which significantly influence } \\
\text { performance of Chinese A-share } \\
\text { companies }\end{array}$ & $\begin{array}{l}\text { The study main object was to assess } \\
\text { the dimensions of involving } \\
\text { stakeholder on performance of green } \\
\text { procurement while our study } \\
\text { concentrated on how stakeholder } \\
\text { involvement affect performance of } \\
\text { Chinese funded project. case study of } \\
\text { One Belt One Road initiative project }\end{array}$ \\
\hline $\begin{array}{l}\text { Miruri and Wanjohi } \\
\text { (2017) }\end{array}$ & $\begin{array}{l}\text { Determinants of performance } \\
\text { of irrigation projects: Case of } \\
\text { Nthawa irrigation project of } \\
\text { Mbeere North Sub-county, } \\
\text { Embu County, Kenya }\end{array}$ & $\begin{array}{l}\text { management, community } \\
\text { participation, resources adequacy, } \\
\text { technology used and availability of } \\
\text { sizable land for irrigation } \\
\text { significantly affect performance of } \\
\text { irrigation projects }\end{array}$ & $\begin{array}{l}\text { The study was conducted on Nthawa } \\
\text { irrigation project of Mbeere North } \\
\text { Sub-county, Embu County while our } \\
\text { study will be conducted on Chinese } \\
\text { funded project in Kenya. case study } \\
\text { of One Belt One Road initiative } \\
\text { project }\end{array}$ \\
\hline $\begin{array}{l}\text { Skorobogatova and } \\
\text { Kuzmina-Merlino } \\
\text { (2017) }\end{array}$ & $\begin{array}{l}\text { Transport infrastructure } \\
\text { development performance }\end{array}$ & $\begin{array}{l}\text { Infrastructure development such as } \\
\text { ICT and road network significantly } \\
\text { influences economic performance. }\end{array}$ & $\begin{array}{l}\text { This study was conducted in Latvia } \\
\text { with special analysis on how } \\
\text { infrastructure development on } \\
\text { economic development of Latvia } \\
\text { while our study will be conducted on } \\
\text { Chinese funded project in Kenya case } \\
\text { study of One Belt One Road initiative } \\
\text { project }\end{array}$ \\
\hline $\begin{array}{l}\text { Oyigbo and Ugwu } \\
(2017)\end{array}$ & $\begin{array}{l}\text { Appraisal of key } \\
\text { performance indicators on } \\
\text { road infrastructure financed } \\
\text { by public-private }\end{array}$ & $\begin{array}{l}\text { Availability of infrastructure } \\
\text { increases asset value, reduces user } \\
\text { cost, reduces public sector } \\
\text { administration costs, increases road } \\
\text { usage, reduces travel time, reduces } \\
\text { maintenance cost and reduces road } \\
\text { accident and increased road network } \\
\text { size is the most significant factor } \\
\text { that affects most operation of the } \\
\text { organizations. }\end{array}$ & $\begin{array}{l}\text { The study concentrated on the road } \\
\text { infrastructure that been financed by } \\
\text { public-private while our study will be } \\
\text { conducted on Chinese funded project } \\
\text { in Kenya case study of One Belt One } \\
\text { Road initiative project }\end{array}$ \\
\hline $\begin{array}{l}\text { Garrido, Gomez, } \\
\text { de los Ángeles Baeza } \\
\text { and Vassallo (2017) }\end{array}$ & $\begin{array}{l}\text { Is EU financial support } \\
\text { enhancing the economic } \\
\text { performance of PPP projects? } \\
\text { An empirical analysis on the } \\
\text { case of spanish road } \\
\text { infrastructure }\end{array}$ & $\begin{array}{l}\text { Financial assisted organization } \\
\text { performed better economically as to } \\
\text { compare the organization that has } \\
\text { not been supported. The study } \\
\text { concluded that there is significant } \\
\text { correlation between performance } \\
\text { and financial support. }\end{array}$ & $\begin{array}{l}\text { The study was conducted on Spanish } \\
\text { road infrastructure projects while our } \\
\text { study will be conducted on Chinese } \\
\text { funded project in Kenya case study of } \\
\text { One Belt One Road initiative project }\end{array}$ \\
\hline $\begin{array}{l}\text { Perkins and Repper } \\
\qquad(2018)\end{array}$ & $\begin{array}{l}\text { The independent review of } \\
\text { mental health legislation: a } \\
\text { real opportunity for change }\end{array}$ & $\begin{array}{l}\text { Firms that conduct forums to discuss } \\
\text { the all matters that affect staff } \\
\text { performance perform better than } \\
\text { their counter parts that have not } \\
\text { engaged their employees. }\end{array}$ & $\begin{array}{l}\text { The study was concentrated on how } \\
\text { mental health effect productivity of } \\
\text { IT firms in South Africa while our } \\
\text { study will be conducted on Chinese } \\
\text { funded project in Kenya case study of } \\
\text { One Belt One Road initiative project }\end{array}$ \\
\hline $\begin{array}{l}\text { Begen, Barnett, Payne, } \\
\text { Gowland, DunnGalvin } \\
\text { and Lucas (2018) }\end{array}$ & $\begin{array}{l}\text { Eating out with a food } \\
\text { allergy in the UK: change in } \\
\text { the eating out practices of } \\
\text { consumers with food allergy } \\
\text { following introduction of } \\
\text { allergen information } \\
\text { legislation }\end{array}$ & $\begin{array}{l}\text { Any improvement in allergen } \\
\text { information provided and riced the } \\
\text { awareness of food allergy. The } \\
\text { findings also identified that this } \\
\text { process also helped in } \\
\text { communication between the staff, } \\
\text { management and their customers }\end{array}$ & $\begin{array}{l}\text { The study was conducted in United } \\
\text { kingdoms while our study will be } \\
\text { conducted on Chinese funded project } \\
\text { in Kenya case study of One Belt One } \\
\text { Road initiative project }\end{array}$ \\
\hline Dvouletý (2017) & $\begin{array}{l}\text { Effects of soft loans and } \\
\text { credit guarantees on } \\
\text { performance of supported } \\
\text { firms: evidence from the } \\
\text { Czech public programme } \\
\text { START }\end{array}$ & $\begin{array}{l}\text { There is a positive impact of } \\
\text { performance of organizational } \\
\text { programme and supported firms } \\
\text { experience higher rate of return in } \\
\text { terms of net profit, return on assets, } \\
\text { and return on equity. }\end{array}$ & $\begin{array}{l}\text { The purpose of this study is to } \\
\text { evaluate the effect of soft loans on } \\
\text { the performance of Czech public } \\
\text { programme START while our study } \\
\text { will be conducted on Chinese funded } \\
\text { project in Kenya case study of One } \\
\text { Belt One Road initiative project }\end{array}$ \\
\hline
\end{tabular}




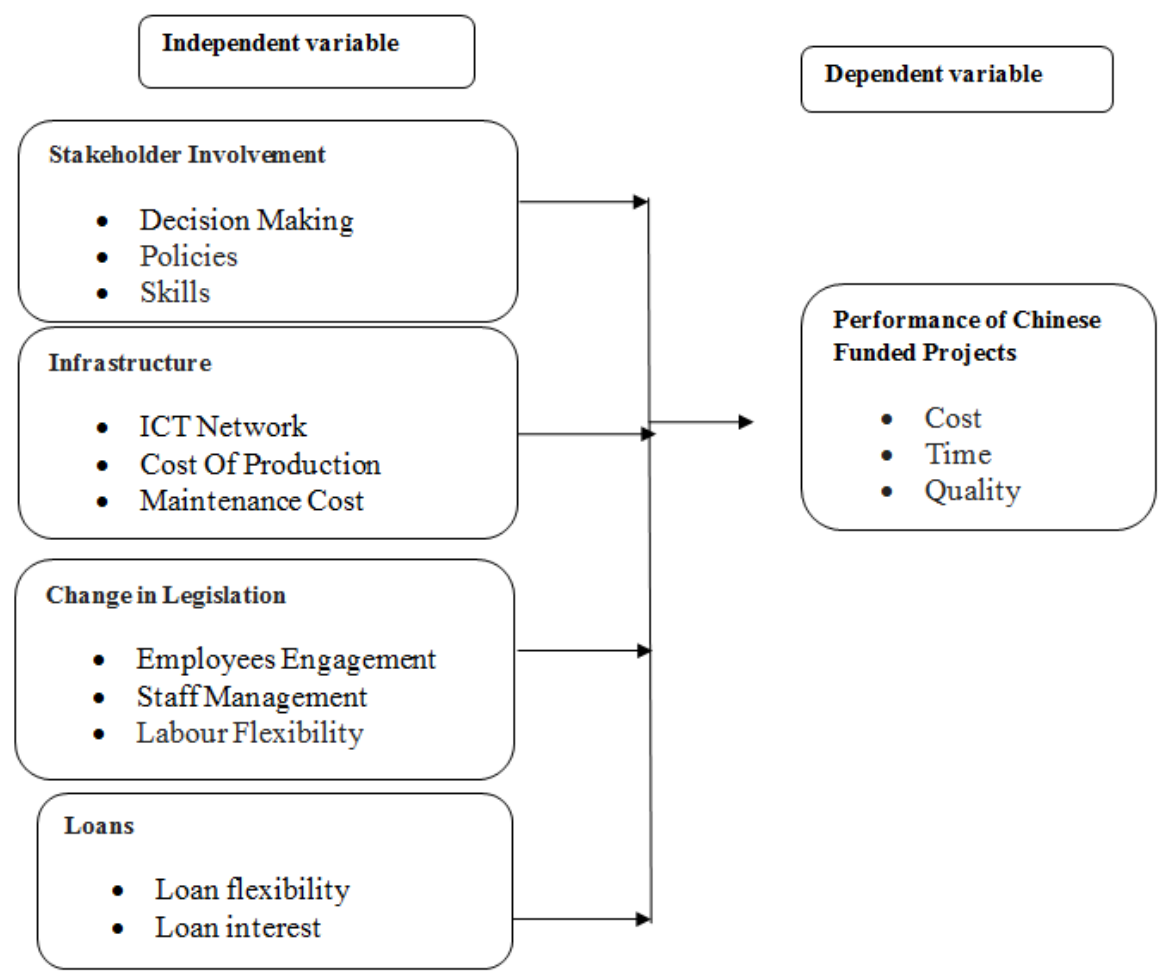

Figure 1. Conceptual Framework

\subsection{Conceptual Framework}

The conceptual framework provides the research with a guideline on how independent and depended variables interact in relation to determinants of performance of "One Belt One Road" initiative project in Kenya. The study will focus on four determinants namely; Stakeholder Involvement, Infrastructure, Change in Legislation and Loans. Each of them will be examined to find out their effects on performance of "One Belt One Road" initiative project in Kenya.

\section{Methodology}

\subsection{Introduction}

This chapter focuses on the methodology that will be used for the study. It highlights the research design, the target population, the sample design, data collection methods, data analysis and ethical issues of the study.

\subsection{Research Design}

This study will use a descriptive survey research design. This type of research describes what exists and may help to uncover new facts and meaning. The purpose of descriptive research is to observe, describe and document aspects of a situation as it naturally occurs (Creswell \& Creswell, 2017). The purpose of a descriptive research project will be to provide a picture of situations as they naturally happen.

\subsection{Target Population}

Yin, (2017) define the target population as a complete set of individuals, case or objects with the same common observable characteristics. This study will focus on Standard Gauge Railway Project funded by the Chinese government as part of One Belt One Road initiative project. The targeted population will entails SGR management staff which will include project coordinator, project manager, government representative from Kenya and China, operating staff and community representative. The target population was therefore 221 respondents as presented in the table below;

Table 2. Target Population

\begin{tabular}{|l|c|c|}
\hline Category & Frequency & Percentage \\
\hline Project Coordinator & 9 & 4.072 \\
\hline Project Manager & 15 & 6.790 \\
\hline Government Representative & 6 & 2.715 \\
\hline Operating staff & 149 & 67.42 \\
\hline Community Representative & 42 & 19.005 \\
\hline Total & 221 & 100 \\
\hline
\end{tabular}

Source: Kenya Railways, 2018

\subsection{Sample Size and Sampling Procedure}

This study used stratified sampling technique in 
selecting managers and directors of SGR. In this case, SGR management staff is better placed in providing information on determinant of performance. In selecting the sample size, this study utilizes sample determination table developed by (Creswell \&Poth, 2017). From the population of 221 a sample was picked for $30 \%$, as total of 66 respondents According to Mugenda and Mugenda (2003), a sample of more than $30 \%$ is representative.

Table 3. Sample Size

\begin{tabular}{|l|c|c|c|}
\hline Category & Frequency & Rate & Sample Size \\
\hline Project Coordinator & 9 & 0.3 & 3 \\
\hline Project Manager & 15 & 0.3 & 4 \\
\hline Government Representative & 6 & 0.3 & 2 \\
\hline Operating staff & 149 & 0.3 & 45 \\
\hline Community Representative & 42 & 0.3 & 12 \\
\hline Total & 221 & 0.3 & 66 \\
\hline
\end{tabular}

Source: Researcher, 2019

\subsection{Data Collection Instrument}

Questionnaires were used as instruments of data collection. The selection of questionnaires as data collection instrument in this research study is informed by the fact that the current study is based on quantitative research approach. According to Yin (2017) observe that administering questionnaires is a popular method for data collection in most disciplines because of the relative ease and cost effectiveness with which they are constructed and administered to large samples. The data will be collected through drop and pick method which is convenient and time saving mode of administering questionnaires. The respondents will be asked to rate various aspects in a Likert scale. The respondents will be required to tick where appropriate indicating their opinion regarding the identity determinant performance of Chinese funded projects in Kenya. Since there could be a chance that some of the respondents chosen would fail to provide the right information, the researcher selected a large number of respondents to ensure that high quality data is collected.

\subsection{Data Collection Procedures}

The data was collected using self-administered questionnaires to the SGR management staff which will include project coordinator, project manager, government representative from Kenya and china, operating staff and community representative. The questionnaires will be administered through drop and pick method where the researcher delivered the questionnaires in person at the respondents' places of work. However, where it will be difficult for the respondents to complete the questionnaire immediately, the researcher left the questionnaires with the respondents and picked them up at a later date.

\subsection{Reliability and Validity of the Study}

\subsubsection{Validity of Research Instrument}

Heale and Twycross (2015) explains validity as the capability of the study's instruments to effectively measure what they are expected to measure. The researcher tested the instrument's internal validity with the objective of measuring if the explanation of specific data is really sustained in its actual data. The researcher used content validity that helps in ensuring that the instruments used fairly measure the items that it was expected to cover. The researcher as well applied construct validity in measuring if the theory and the construct correlate (LoBiondo \& Haber, 2014).

\subsubsection{Reliability of Research Instrument}

The researcher tested for reliability of the research instruments by use of Cronbach alpha. Reliability measures the consistency of the research instrument used. Cronbach's alpha is one of the most widely used measures of reliability in the social and organizational sciences (Furler, 2013). Cronbach's is a function of the number of items in a test, the average covariance between item-pairs, and the variance of the total score. The threshold of Cronbach alpha is 0.7 which depict that the research instruments are consistent (Cronbach, 1950).

\subsection{Data Analysis and Presentation}

The collected data was analyzed to summarize the essential features and relationships of data in order to generalize and determine patterns of behavior and particular outcomes. Before processing the responses, the completed questionnaires information were edited for completeness and consistency and then coded. The obtained questionnaires data were coded and organized in excel spread sheet and analysis was done through excel and SPSS software. The results of the analysis was presented in the form of tables and percentages in a manner that is both simple and comprehensive and then use to complete the research report as per the survey objectives and research questions.

In addition, the researcher is to conduct a multiple regression analysis in order to establish the determinates of performance Chinese Funded Projects in Kenya taking a keen look at Standard Gauge Railway Project funded by the Chinese government. Regression analysis was used to predict the value of the dependent variable on the basis of the independent variables. The used regression analysis was concerned with the study of the dependence of one variable, or more other variables, the explanatory variables, with a view to estimating and or predicting the population mean. The multivariate regression equation was:

$$
Y=\beta+\beta_{1} X_{1}+\beta_{2} X_{2}+\beta_{3} X_{3}+\beta_{4} X_{4}+\varepsilon
$$

Whereby: 
$\mathrm{Y}=$ Performance of One Belt One Road initiative project $\beta$, $\beta_{1}, \beta_{2}, \beta_{3}$ and $\beta_{4}$ are constants

$\varepsilon$ is an error term

$\mathrm{X} 1=$ Stakeholder Involvement

$\mathrm{X} 2=$ Infrastructure

$\mathrm{X} 3=$ Change In Legislation

X4= Loans

The study was tested using Analysis of Variance (ANOVA) to establish the significance of the model in estimating the relationship between the dependent and independent variables.

\subsection{Ethical Consideration}

The researcher obtained an introductory and research authorization letter from the institution stating the main purpose of the research and how the research maintained the privacy and confidentiality of information that was obtained from the respondents. The purpose, the duration of the participation and the benefits of the study were communicated to all the participants in advance.

\section{Research Findings and Discussions}

\subsection{Introduction}

This study sought to assess the determinants of the performance of Chinese funded projects in Kenya with a special focus on the One Belt One Road Initiative. The Standard Gauge Railway project is the pioneer in the initiative and the respondents were picked from the project. The main determinants focused on were stakeholder involvement, infrastructure, change in legislation and loans and their effect on project performance analyzed. The study targeted 221 project staff who included project coordinators, project managers, government representative from both China and Kenya, operational staff and community representatives. A sample of 66 respondents was randomly chosen who were given questionnaires that were subsequently used in data analysis. The data was analyzed using both descriptive and inferential statistics and presented using means, standard deviation, frequencies and percentages.

\subsubsection{Response Rate}

The study sample size was 66 representing project management team, government representatives, operations staff and community representatives. Out of the 66 questionnaires distributed to the respondents, 60 of them were completed and returned. This gave a response rate of $90.91 \%$ which is deemed sufficient for the study as presented in the figure below;

Table 4. Response rate

\begin{tabular}{|c|c|c|}
\hline Rate & Frequency & Percentage \\
\hline Response & 60 & 90.91 \\
\hline Non-response & 6 & 9.09 \\
\hline Total & $\mathbf{6 6}$ & $\mathbf{1 0 0}$ \\
\hline
\end{tabular}

Source: Field data, 2019

The findings show that the response rate was sufficient for the current study. This is supported by Mugenda and Mugenda (2003) who stated that a sample size of $70 \%$ and above is deemed statistically sufficient for a study.

\subsubsection{Reliability Test}

The researcher conducted a reliability test for the questionnaires used to collect data using the Cronbach's Alpha coefficient. A Cronbach alpha was computed for each of the variables and the overall coefficient determined. The findings were as shown in Table 5.

Table 5. Reliability Test

\begin{tabular}{|c|c|c|}
\hline Variable & Number of Items & Cronbach Alpha \\
\hline $\begin{array}{c}\text { Stakeholder } \\
\text { Involvement }\end{array}$ & 5 & 0.781 \\
\hline Infrastructure & 5 & 0.806 \\
\hline Change in Legislation & 5 & 0.759 \\
\hline Loans & 5 & 0.811 \\
\hline $\begin{array}{c}\text { Overall Cronbach } \\
\text { Coefficient }\end{array}$ & & $\mathbf{0 . 7 8 9}$ \\
\hline
\end{tabular}

Source: Field, 2019

The finding established that stakeholder involvement had a Cronbach coefficient of 0.781 ; infrastructure had a Cronbach alpha coefficient of 0.806. Change in legislation had a Cronbach alpha coefficient of 0.759 and loans had a Cronbach alpha coefficient of 0.811 . The overall Cronbach coefficient was 0.789 which was above 0.7 an indication that the research instruments were reliable for the study. This is supported by Cronbach (1951) who stated that a Cronbach alpha of 0.7 and above is deemed sufficient for the study.

\subsection{Demographic Background}

The study assessed the bio-demographic characteristics of the respondents ranging from gender, age, highest education level to years worked at the organization. The findings were as presented below;

\subsubsection{Gender of Respondents}

The study sought to find out the respondents gender in the Chinese funded projects in Kenya. The findings were as presented in the pie chart below; 


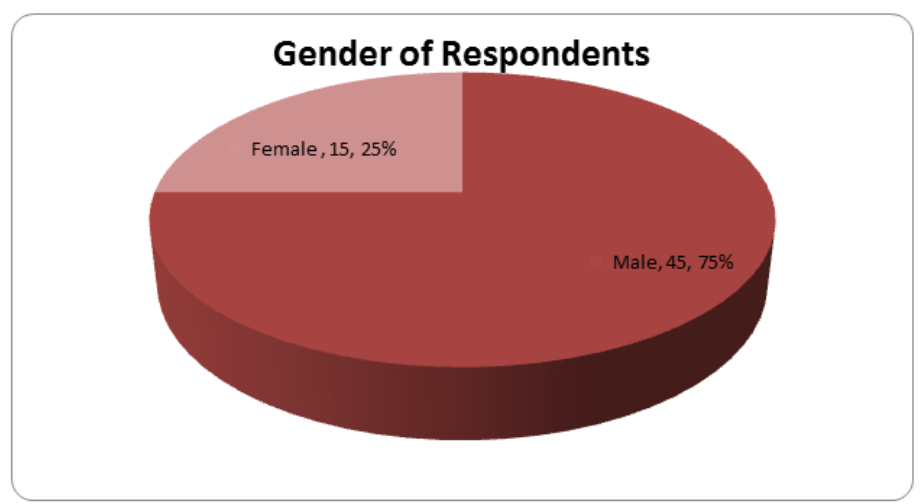

Source: Field data, 2019

Figure 2. Gender of Respondents

The study established that $75 \%$ of the respondents who were SGR staff were male while $25 \%$ were female. This indicates that most of the management staff were male. However either gender was represented in the study.

\subsubsection{Age of Respondents}

The study further sought to assess the age distribution of the respondents. The findings were as tabulated below;

Table 6. Respondents' Age

\begin{tabular}{|c|c|c|}
\hline Age bracket & Frequency & Percentage \\
\hline Under 30 years & 21 & 35.00 \\
\hline $31-40$ years & 28 & 46.67 \\
\hline 41 and above years & 11 & 18.33 \\
\hline Total & 60 & 100 \\
\hline
\end{tabular}

Source: Field data, 2019

The study established that $35 \%$ of the respondents were under 30 years, $46.67 \%$ of them were between 31 and 40 years, $18.33 \%$ of them were 41 years and above. The study indicated that most of the project management staff were young people whose potential to perform was high.

\subsubsection{Education Level}

The study further sought to establish the education level of the project management staff in the Standard Railway Gauge Project in Kenya. The findings were as presented below;

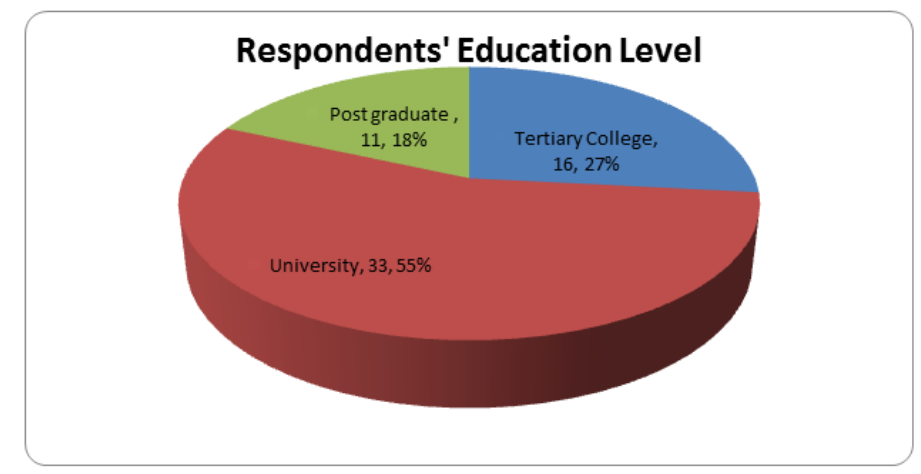

Source: Field data, 2019

Figure 3. Education Level of Respondents

The study indicated that $27 \%$ of the respondents were tertiary college graduates, $55 \%$ were university graduates while $18 \%$ had post-graduate qualifications. This indicates that most of the respondents had at least a university degree. This indicates that the management staff at the SGR had the pre-requisite academic qualifications to perform their duties and responsibilities well. 


\subsubsection{Period in the Organization}

The study sought to establish the number of years the respondents had been involved in the SGR project. The findings were as presented below;

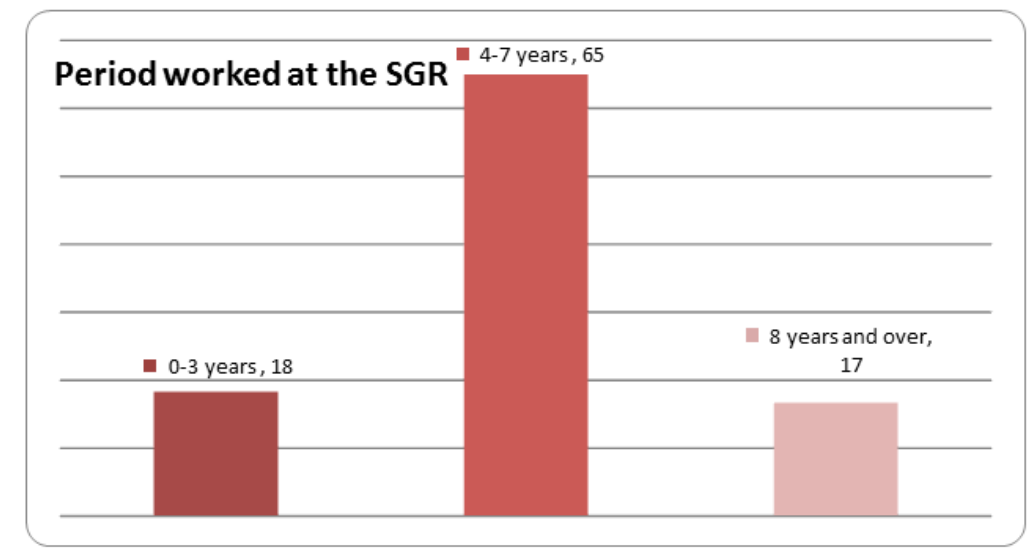

Source: Field data 2019

Figure 4. Period worked at the project

The study established that $18 \%$ of the management staff at the One Belt One Road initiative project had worked for less than 3 years, $65 \%$ had worked for between 4 and 7 years, $17 \%$ of them had worked for more than 8 years. This indicates that most of the respondents were more than 4 years old in the project. This indicates that they had significant understanding on the operations and performance trend and challenges of the SGR project.

\subsection{Descriptive Findings}

\subsubsection{Stakeholder Involvement and Project Performance}

The study respondents were requested to indicated their level of agreement or disagreement with the following statements relating to the effect of stakeholder involvement on performance of Chinese funded projects in Kenya on a likert scale of 1-5 where 1- Strongly disagree, 2-disagree, 3-undecided, 4- agree, 5- strongly agree. The findings were presented in terms of means and standard deviations as tabulated below;

Table 7. Stakeholder Involvement and Project Performance

\begin{tabular}{|l|c|c|}
\hline \multicolumn{1}{|c|}{ Statement } & Mean & Std. Dev \\
\hline $\begin{array}{l}\text { We are included in the decision making of our } \\
\text { organization. }\end{array}$ & 3.02 & 0.771 \\
\hline $\begin{array}{l}\text { The policies formulated by our organization } \\
\text { is allows full participation of the employees }\end{array}$ & 3.11 & 0.840 \\
\hline $\begin{array}{l}\text { We are committed to our work because of } \\
\text { favorable policies. }\end{array}$ & 2.86 & 0.833 \\
\hline $\begin{array}{l}\text { Top management in our organization delegate } \\
\text { responsibilities to the project teams. }\end{array}$ & 3.47 & 0.791 \\
\hline $\begin{array}{l}\text { We are motivated by favorable policies that } \\
\text { have been formed in our organization. }\end{array}$ & 2.76 & 0.803 \\
\hline $\begin{array}{l}\text { Our organization support our development } \\
\text { through training }\end{array}$ & 3.29 & 0.617 \\
\hline $\begin{array}{l}\text { Our organization always conduct forums for } \\
\text { discussion }\end{array}$ & 2.64 & 0.852 \\
\hline
\end{tabular}

Source: Field data, 2019
The study established that to a moderate extent the stakeholders are included in the decision making of the project, the policies formulated by the organization allows full participation of the employees, the staff are committed to their work because of favorable policies, top management in the project delegate responsibilities to the project teams, they are motivated by favorable policies that have been formed in their organization, their project support their development through training and that the project always conduct forums for discussion with all stakeholders as indicated by a mean of $3.02,3.11,2.86$, $3.47,2.76,3.29$ and 2.64 respectively. This indicates that the project embraced stakeholder involvement to a significant extent despite of the challenges faced by not sufficiently including them, incorporating their feedback and expectations in the project. The project team was significantly included in project decision making, policy formulation, discussions and responsibility delegation. This contributed to improved project performance as also concluded by Song, Yu \& Zhang (2017) in their study on stakeholder satisfaction operational performance of projects among Chinese A-Share companies established that firms focus on stakeholder involvement on decision making since it significantly influences project performance.

\subsubsection{Infrastructure and Performance Chinese funded Projects}

The second objective of the study was to establish the effect of infrastructure on the performance of the one belt one road imitative project in Kenya. The respondents were the asked to indicate the extent to which the following aspects of infrastructure affect performance of Chinese funded projects in Kenya on a scale of 1-5 where 1Strongly disagree, 2-disagree, 3-undecided, 4- agree, 5strongly agree. The findings were as presented in the table 
below;

Table 8. Infrastructure and Project Performance

\begin{tabular}{|l|c|c|}
\hline \multicolumn{1}{|c|}{ Statement } & Mean & Std. Dev \\
\hline $\begin{array}{l}\text { Our organization have formulated policies to } \\
\text { control information technology network }\end{array}$ & 3.56 & 0.679 \\
\hline We have invested heavily on road network & 3.57 & 0.901 \\
\hline $\begin{array}{l}\text { Road network coverage affect our distribution } \\
\text { mechanism }\end{array}$ & 3.94 & 0.775 \\
\hline $\begin{array}{l}\text { We are assisted by investment in development } \\
\text { of infrastructures. }\end{array}$ & 3.66 & 0.824 \\
\hline $\begin{array}{l}\text { We have adequate technology incorporated in } \\
\text { our daily activities }\end{array}$ & 3.51 & 0.866 \\
\hline $\begin{array}{l}\text { The technology tool used by our project is in } \\
\text { line with our organization vision. }\end{array}$ & 3.71 & 0.857 \\
\hline
\end{tabular}

Source: Field data, 2019

The study respondents significantly agreed that their organization has formulated policies to control information technology network, the organization has invested heavily on road network, road network coverage affects their distribution mechanism, they are assisted by investment in development of infrastructure, they have adequate technology incorporated in their daily activities and that the technology tool used by their project is in line with their organization vision as indicated by a mean of $3.56,3.57$, $3.94,3.66,3.51$ and 3.71 respectively. The study therefore established that to a great extent project policy framework on technology, road network and continued investment in infrastructure has influenced project performance. Skorobogatova and Kuzmina-Merlino (2017) in their study on the transport infrastructure development performance in Latvia similarly indicated that infrastructure development such ICT and road network significantly influences economic and project performance.

\subsubsection{Change in Legislation and Project Performance}

Legislation entails coming up or existence of relevant policies, regulations and lawsgoverning projects and their implementation. The study respondents were therefore asked to indicated the degree to which the following statements on change in legislation affect performance of Chinese funded projects in Kenya on a scale of 1-5 where 1- Strongly disagree, 2-disagree, 3-undecided, 4- agree, 5strongly agree. The findings were as presented below;

Table 9. Change in Legislation and Project Performance

\begin{tabular}{|l|c|c|}
\hline \multicolumn{1}{|c|}{ Statement } & Mean & Std. Dev \\
\hline $\begin{array}{l}\text { Our organization always conduct forums to } \\
\text { discuss all matters that affect staff }\end{array}$ & 3.04 & 0.837 \\
\hline Our staff are always committed to their work & 3.28 & 0.825 \\
\hline $\begin{array}{l}\text { Our organization have laid down } \\
\text { communication procedures between the staff, } \\
\text { management and their customers }\end{array}$ & 3.39 & 0.841 \\
\hline $\begin{array}{l}\text { Our organization strengthens employment } \\
\text { protection legislation processes }\end{array}$ & 3.41 & 0.697 \\
\hline Structural reforms supports labor flexibility & 2.91 & 0.791 \\
\hline $\begin{array}{l}\text { We have cost-effective financial structures in } \\
\text { our organization }\end{array}$ & 3.22 & 0.877 \\
\hline
\end{tabular}

Source: Field data, 2019
The study respondents were neutral or to a moderate extent indicated that their organization always conduct forums to discuss all matters that affect staff, their staffs are always committed to their work, their organization has laid down communication procedures between staff, management and customers, their organization strengthens employment protection legislation processes, structural reforms support labor flexibility and that there are cost effective financial structures in their organization as indicated by a mean of 3.04, 3.28, 3.39, 3.41, 2.91 and 3.22 respectively. The study therefore established that to a moderate extent had favorable legislations through personnel management, communication, employee protection, structural reforms and cost-effectiveness which contribute positively to project performance. Perkins and Repper (2018) in their review of health legislation on the productivity of IT firms in South Africa realized that legislations provide guidelines, policies and regulations upon which a firm or project operates and adheres to ,which directly and indirectly affects its performance.

\subsubsection{Loans and Project Performance}

Further the study sought to establish the extent to which the respondents rated the following statements on loans as modes of facilitating the SGR project under the One belt One Road Initiative and the effect they had on the performance of the project on a scale of 1-5 where 1Strongly disagree, 2-disagree, 3-undecided, 4- agree, 5strongly agree. The findings were as presented below;

Table 10. Loans and Project Performance

\begin{tabular}{|l|c|c|}
\hline \multicolumn{1}{|c|}{ Statement } & Mean & Std. Dev \\
\hline $\begin{array}{l}\text { Our organization acquires soft loans and credit } \\
\text { guarantees from financial institutions. }\end{array}$ & 4.41 & 0.824 \\
\hline $\begin{array}{l}\text { We acquire financial assistance at lower credit } \\
\text { rates. }\end{array}$ & 3.67 & 0.861 \\
\hline $\begin{array}{l}\text { We have storage mechanism to store financial } \\
\text { statements }\end{array}$ & 3.94 & 0.694 \\
\hline Our organization repay their loans on time & 3.22 & 0.831 \\
\hline Loans are always accessed fully online & 3.24 & 0.719 \\
\hline $\begin{array}{l}\text { Financial institution always carries out training } \\
\text { on product they offer in our organization. }\end{array}$ & 3.31 & 0.599 \\
\hline
\end{tabular}

Source: Field data, 2019

The respondents significantly agreed that their organization acquires soft loans and credit guarantees from financial institutions, they acquire financial assistance at lower credit rates and that they have storage mechanism to store financial statements as indicated by a mean of 4.41 , 3.67 and 3.94 respectively. The respondents were neutral or to a moderate extent indicated that their organization repays its loan on time, loans are always access fully online and that financial institutions always carry out training on products they offer in their project as indicated by a mean of $3.22,3.24$ and 3.31 respectively. It was therefore indicated that the project relied heavily on loans from the Chinese government, which were sufficiently access but 
repayment was ongoing and had a long period of time. Dvouletv (2017) in their study on the effects of soft loans and credit guarantees on performance of supported firms in Czech Republic similarly indicated that there is a positive impact of soft loans and credit on the performance of firms and the projects they undertake although they need diligent use and accountability.

\subsubsection{Project Performance}

The study sought to establish the determinants of the performance of Chinese funded projects in Kenya. The dependent variable was therefore performance of the SGR project which was selected for analysis. The respondents were therefore asked to indicated the extent to which they agreed with the following indicators of project performance as they applied in their organization on a scale of 1-5 where 1- Strongly disagree, 2-disagree, 3-undecided, 4- agree, 5- strongly agree. The findings were as presented in the table below;

Table 11. Project Performance

\begin{tabular}{|l|c|c|}
\hline Performance Indicators & Mean & Std. Dev \\
\hline The project is being implemented within Cost & 3.52 & 0.881 \\
\hline The project is on schedule & 3.66 & 0.768 \\
\hline Quality is not compromised & 3.97 & 0.914 \\
\hline The project is within budget & 3.04 & 0.822 \\
\hline
\end{tabular}

Source: Field data, 2019

The respondents agreed that the project is cost effective; it is within schedule and quality as indicated by a mean of $3.52,3.66$ and 3.97 respectively. The respondents were however neutral on whether the project was within budget as indicated by a mean of 3.04 and standard deviation of 0.822 respectively. This indicates that to a significant extent, the project was performing within scope, time, budget and quality.

\subsection{Inferential Statistics}

The study used inferential statistics to establish the correlation between the independent and dependent variables of the study. The findings of Model Summary, ANOVA and Coefficient of Regression were as indicated in the following sections.

\subsubsection{Model Summary}

The findings of coefficient of correlation and coefficient of determination are as shown in Table 4.9.

Table 12. Model summary

\begin{tabular}{|c|c|c|c|c|}
\hline Model & $\mathrm{R}$ & $\mathrm{R}$ square & $\begin{array}{c}\text { Adjusted } \mathrm{r} \\
\text { square }\end{array}$ & $\begin{array}{c}\text { Std. Error of the } \\
\text { estimate }\end{array}$ \\
\hline 1 & $.839^{\mathrm{a}}$ & .811 & .827 & 1.34607 \\
\hline
\end{tabular}

Predictors: (constant), stakeholder involvement, infrastructure change in legislation and loans.

Source: Field data, 2019

The study shows that coefficient of correlation $\mathrm{R}$ of 0.839 an indication of strong of correlation between the variables. Coefficient of adjusted $\mathrm{R}^{2}$ was 0.827 which translates to $82.7 \%$. This show that changes in dependent variable can significantly and sufficiently be explained by independent variables (stakeholder involvement, infrastructure change in legislation and loans). The residual of $17.3 \%$ can be explained by other variables not incorporated in the current study.

\subsubsection{ANOVA}

An ANOVA was conducted at 95\% level of significance. The findings of $\mathrm{F}_{\text {Calculated }}$ and $\mathrm{F}_{\text {Critical }}$ are as shown in Table 13.

Table 13. ANOVA

\begin{tabular}{|c|c|c|c|c|c|}
\hline Model & $\begin{array}{c}\text { Sum of } \\
\text { squares }\end{array}$ & Df & $\begin{array}{c}\text { Mean } \\
\text { square }\end{array}$ & F & Sig. \\
\hline Regression & 679.251 & 9 & 75.4723 & 10.1004 & $.000^{\mathrm{b}}$ \\
\hline Residual & 381.081 & 51 & 7.4722 & & \\
\hline Total & 1060.332 & 60 & & & \\
\hline
\end{tabular}

a. Dependent variable: Project Performance

b. Predictors: (constant), stakeholder involvement, infrastructure change in legislation and loans)

Source: Field data, 2019

It was established that the study had $\mathrm{F}_{\text {Calculated }}$ of 10.1004 and $\mathrm{F}_{\text {Critical }}$ was 3.6671, this show that of $\mathrm{F}_{\text {Calculated }}>\mathrm{F}_{\text {Critical }}$ an indication that the overall regression model was significant for the study. The $\mathrm{p}$ value was $0.00<0.05$ an indication that at least one independent variable significantly influenced the performance the Chinese funded projects in Kenya.

\subsubsection{Regression Coefficient}

The study used a regression coefficient to establish the determinants of the performance of Chinese funded projects in Kenya. The findings are indicated in Table 14. 
Table 14. Regression Coefficient

\begin{tabular}{|c|c|c|c|c|c|}
\hline \multirow{2}{*}{ Model } & \multicolumn{2}{|c|}{ Unstandardized coefficients } & \multirow{2}{*}{$\begin{array}{c}\text { Standardized } \\
\text { coefficients } \\
\text { Beta }\end{array}$} & \multirow{2}{*}{$\mathbf{T}$} & \multirow{2}{*}{ Sig. } \\
\hline & B & Std. Error & & & \\
\hline (constant) & 7.413 & 2.162 & & 2.422 & .000 \\
\hline Stakeholder involvement & 0.816 & .034 & .342 & 2.254 & .000 \\
\hline Infrastructure & 0.898 & .067 & .125 & 3.324 & .000 \\
\hline Changes in legislation & 0.679 & .081 & .247 & 2.504 & .000 \\
\hline Loans & 0.847 & .069 & .148 & 2.388 & .000 \\
\hline
\end{tabular}

Dependent variable: Project Performance

Source: Field data, 2019

$\mathrm{Y}=7.413+0.816 \mathrm{X}_{1}+0.898 \mathrm{X}_{2}+0.669 \mathrm{X}_{3}+0.847 \mathrm{X}_{4}$

Whereby:

$\mathrm{Y}=$ Performance of the SGR

$\mathrm{X} 1=$ Stakeholder involvement

$\mathrm{X} 2=$ Infrastructure

$\mathrm{X} 3=$ Changes in legislation

$\mathrm{X} 4=$ Loans

Table 14 indicates that all variables held constant, performance of the Chinese funded projects would be at 7.413. A unit increase in stakeholder involvement while holding other variables constant, project performance would be at 0.816 . A unit increase in infrastructural development while holding other factors constant, performance of the project would be at 0.898. A unit increase in legislation of relevant and favorable regulations and policies while holding other factors constant, project performance would be at 0.669. A unit increase in availability and disbursement of loans while holding other factors constant, performance of the project would be at 0.847 .

The $\mathrm{p}$ values of all the independent variables which include stakeholder involvement, infrastructure change in legislation and loans were $0.000<0.05$ indicating that the variables significantly influenced performance of Chinese funded projects in Kenya. This is supported by a study by Begen et al (2018) who in their study on factors affecting implementation of projects in the UK established that the selected factors had a significant effect on project performance.

\section{Summary, Conclusions and Recommendations}

\subsection{Introduction}

This chapter presents the summary of the findings of the study as presented and discussed in the previous chapter. The study conclusions and recommendations are enumerated based on the findings; suggestions for further studies are also provided.

\subsection{Summary of the Findings}

The main objective of the study was to assess the determinants of the performance of Chinese funded projects in Kenya; case of One Belt One Road Initiative Project. The study sought to establish the effect of stakeholder involvement, infrastructure, change in legislation and loans on the performance of the SGR project which is the pioneer project of the initiative. The response rate was $920.91 \%$ which was deemed sufficiently representative. The average Cronbach alpha was 0.789 making the questionnaires statistically reliable. The adjusted R Square was 0.827 which indicates that determinants identified influenced $82.7 \%$ of the performance of the selected projects. Both descriptive and inferential statistics were used to analyze and present data.

\subsubsection{Stakeholder Involvement and Performance of Chinese Projects in Kenya}

The study established that stakeholder involvement positively and significantly influenced performance of Chinese projects in Kenya. The study established that to a moderate extent the stakeholders are included in the decision making of the project, the policies formulated by the organization allows full participation of the employees, the staff are committed to their work because of favorable policies, top management in the project delegate responsibilities to the project teams, they are motivated by favorable policies that have been formed in their organization, their project support their development through training and that the project always conduct forums for discussion with all stakeholders. The project team was significantly included in project decision making, policy formulation, discussions and responsibility delegation. This contributed to improved project performance.

\subsubsection{Infrastructure and Performance of Chinese Funded Projects in Kenya}

The study established that infrastructure significantly influenced performance of Chinese funded projects in 
Kenya. The study respondents significantly agreed that their organization has formulated policies to control information technology network, the organization has invested heavily on road network, road network coverage affects their distribution mechanism, they are assisted by investment in development of infrastructure, they have adequate technology incorporated in their daily activities and that the technology tool used by their project is in line with their organization vision. The study therefore established that to a great extent project policy framework on technology, road network and continued investment in infrastructure has influenced project performance.

\subsubsection{Change in Legislation and Performance of Chinese Funded Projects in Kenya}

The study pointed out that change in legislation in favour of a project positively influenced performance of Chinese funded projects in Kenya and vice versa. The study established that to a moderate extent indicated that their organization always conduct forums to discuss all matters that affect staff, their staffs are always committed to their work, their organization has laid down communication procedures between staff, management and customers, their organization strengthens employment protection legislation processes, structural reforms support labor flexibility and that there are cost effective financial structures in their organization. The study therefore established that to a moderate extent had favorable legislations through personnel management, communication, employee protection, structural reforms and cost-effectiveness which contribute positively to project performance.

\subsubsection{Loans and Performance of Chinese Funded Projects in Kenya}

The study established that availability, affordability and reliability of loans significantly influenced performance of Chinese funded projects in Kenya. The study established that the organization acquires soft loans and credit guarantees from financial institutions, they acquire financial assistance at lower credit rates and that they have storage mechanism to store financial statements. The respondents were neutral or to a moderate extent indicated that their organization repays its loan on time, loans are always access fully online and that financial institutions always carry out training on products they offer in their project. It was therefore indicated that the project relied heavily on loans from the Chinese government, which were sufficiently access but repayment was ongoing and had a long period of time.

\subsection{Conclusions}

The study concluded that the selected determinants to a significant extent influenced the performance of Chinese funded projects in Kenya. The study concluded that the projects embraced stakeholder involvement to a significant extent despite of the challenges faced by not sufficiently including them, incorporating their feedback and expectations in the project.

The study concluded that to a great extent project policy framework on technology, road network and continued investment in infrastructure has influenced project performance

The study concluded that the projects relied heavily on loans from the Chinese government, which were sufficiently access but repayment was ongoing and had a long period of time

\subsection{Recommendations}

The study recommends that the project management should improve stakeholder involvement, participation and consultation and also incorporate their feedback in the project implementation cycle to foster project performance.

The projects should work on improving infrastructure to facilitate project delivery through use of modern technology and available road network to ensure the project is implemented in time.

The study recommends that the projects should ensure that there is due diligence before a loan or credit is sourced, enhance accountability, transparency and integrity in use of resources and the loans granted.

\subsection{Suggestions for Further Studies}

It was recommended further studies be done on other Chinese projects in Kenya a part from SGR. The study recommends a similar study to be carried out by use of secondary data. The current study had a coefficient of adjusted $R^{2}$ of 0.827 and a residual of $17.3 \%$ which can be explained by other variables beyond the scope of the current study that future scholars should focus on. The main objective of the study was to establish the determinants of the performance of Chinese projects in Kenya, future scholars should carry out similar studies on other determinants apart from the ones selected, other sectors or projects.

\section{Acknowledgements}

First, I am thankful to God for giving me an opportunity to study Executive Masters of business at Kenyatta University. A lot of appreciation goes to my supervisor, Dr. James Maingi who dedicated his time towards this research project. I am glad for his great guidance, support, recommendations and criticisms towards this project. I also thank my family for the unwavering support they gave me when doing this project. Lastly, I also acknowledge the help I received from persons, who helped me directly or indirectly, thank you all. 


\section{Abbreviation and Acronyms}

ANOVA: Analysis of Variance

BRI: Belt and Road Initiative

NACOSTI: National Commission for Science, Technology and Innovation

PPPs: Public-Private Partnerships

ROA: Return on Assets

ROI: Return on Investment

SGR: Standard Gauge Railway Project

SPSS: Statistical Package for the Social Sciences

WPC: World Pension Council

\section{Operational Definition of Terms}

Project Performance: This is how a project accomplishes the indicators of quality, cost and timeliness.

One Belt One Road Project: This project is/are projects initiated by the Chinese government whose main objective is to improve 152 countries infrastructure development and investment status of the countries involved.

Stakeholders Involvement: This refers to the management, employers and all individuals involved in project implementation.

Infrastructure: Refers to the fundamental facilities and systems serving a country, city, or other area, including the services and facilities necessary for its economy to function.

Legislation: Is law which has been promulgated by a legislature or other governing body or the process of making it. Before an item of legislation becomes law it may be known as a bill, and may be broadly referred to as "legislation", while it remains under consideration to distinguish it from other business.

Loan: Is the lending of money by one or more individuals, organizations, or other entities to other individuals, organizations.

\section{Appendix}

\section{APPENDIX I: QUESTIONNAIRE}

\section{Letter of introduction}

Dear respondent,

I am an MBA student at Kenyatta University carrying out a research on "DETERMINANTS OF THE PERFORMANCE OF CHINESE FUNDED PROJECTS IN KENYA-A CASE OF "ONE BELT ONE ROAD" INITIATIVE PROJECTS."

The research is meant for academic purpose only. You are kindly requested to provide answers to these questions as honestly and precisely as possible. The information provided will be kept confidential. In case of any questions kindly contact the undersigned.

Your assistance will highly be appreciated.

Thank you.

Yours faithfully,

XIA ANQUAN

Contact number: 0738565876

Please give answers in the spaces provided and tick $(\sqrt{ })$ in the box that matches your response to the questions where applicable.

\section{SECTION A: DEMOGRAPHIC CHARACTERISTICS}

1. What is your gender?

Male ( ) Female ( ) 
2. What is your age?

Under 30 Years ( ) 31-40 years ( ) 41 years and over ( )

3. What is your highest level of education qualification? (Tick as applicable)

a) Tertiary College ( )

b) University ( )

c) Post graduate ( )

4. Years that you have been involved in your organization?
a) $0-3$ years ()
b) 4-7 years ( )
c) 8 years and over ( )

\section{SECTION B: Stakeholder Involvement and Performance}

5. What is the effect of Stakeholder Involvement on performance of Chinese funded projects in Kenya? Use 1- Strongly disagree, 2-disagree, 3-undecided, 4- agree, 5- strongly agree

\begin{tabular}{|c|c|c|c|c|c|}
\hline Statement & 1 & 2 & 3 & 4 & 5 \\
\hline \multicolumn{6}{|l|}{ We are included in the decision making of our organization. } \\
\hline \multicolumn{6}{|c|}{ The policies formulated by our organization is allows full participation of the employees } \\
\hline \multicolumn{6}{|l|}{ We are committed to our work because of favorable policies. } \\
\hline \multicolumn{6}{|c|}{ Top management in our organization delegate responsibilities to the project teams. } \\
\hline \multicolumn{6}{|c|}{ We are motivated by favorable policies that have been formed in our organization. } \\
\hline \multicolumn{6}{|l|}{ Our organization support our development through training } \\
\hline Our organization always conduct forums for discussion & & & & & \\
\hline
\end{tabular}

\section{SECTION C: Infrastructure and Performance}

6. To what extent does Infrastructure affect performance of Chinese funded projects in Kenya? Use 1- Strongly disagree, 2-disagree, 3-undecided, 4- agree, 5- strongly agree

\begin{tabular}{|c|c|c|c|c|c|}
\hline Statement & 1 & 2 & 3 & 4 & 5 \\
\hline \multicolumn{6}{|c|}{ Our organization have formulated policies to control information technology network } \\
\hline \multicolumn{6}{|l|}{ We have invested heavily on road network } \\
\hline \multicolumn{6}{|l|}{ Road network coverage affect our distribution mechanism } \\
\hline \multicolumn{6}{|l|}{ We are assisted by invested in development of infrastructures. } \\
\hline \multicolumn{6}{|l|}{ We have adequate technology incorporated in our daily activities } \\
\hline The technology tool used by us is in line with our organization vision. & & & & & \\
\hline
\end{tabular}

\section{SECTION D: Change in Legislation and Performance}

7. What is the effect of Change in Legislation on performance of Chinese funded projects in Kenya? Use 1- Strongly disagree, 2-disagree, 3-undecided, 4- agree, 5- strongly agree

\begin{tabular}{|c|c|c|c|c|c|}
\hline Statement & 1 & 2 & 3 & 4 & 5 \\
\hline \multicolumn{6}{|c|}{ Our organizations always conduct forums to discuss the all matters that affect staff } \\
\hline \multicolumn{6}{|l|}{ Our staff are always committed to their work } \\
\hline \multicolumn{6}{|c|}{$\begin{array}{l}\text { Our organization have laid down communication procedures between the staff, management } \\
\text { and their customers }\end{array}$} \\
\hline \multicolumn{6}{|c|}{ Our organization strengths employment protection legislation processes } \\
\hline \multicolumn{6}{|l|}{ Structural reforms supports labor flexibility } \\
\hline We have cost-effective financial structures in our organization & & & & & \\
\hline
\end{tabular}




\section{Section E: Loans and Performance}

8. What is the effect of Loans on performance of Chinese funded projects in Kenya? Use 1- Strongly disagree, 2-disagree, 3 -undecided, 4- agree, 5- strongly agree

\begin{tabular}{|c|c|c|c|c|c|}
\hline Statement & 1 & 2 & 3 & 4 & 5 \\
\hline \multicolumn{6}{|l|}{ Our organization acquires soft loans and credit guarantees from financial institutions. } \\
\hline \multicolumn{6}{|l|}{ We acquire financial assistance at lower credit rates. } \\
\hline \multicolumn{6}{|l|}{ We have storage mechanism to store financial statements } \\
\hline \multicolumn{6}{|l|}{ Our organization repay their loans on time } \\
\hline \multicolumn{6}{|l|}{ Loans are always accessed fully online } \\
\hline Financial institution always carries out training on product they offer in our organization. & & & & & \\
\hline
\end{tabular}

\section{SECTION F: Firm Performance Indicators}

9. Below are some of the firm performance indicators that are affected by determinants of performance. Please indicate the extent to which you agree with the measures of firm performance that have been most affected by this determinants.

Use 1- Strongly disagree, 2-disagree, 3-undecided, 4- agree, 5- strongly agree.

\begin{tabular}{|l|l|l|l|l|l|}
\hline Firms Performance Indicator & 1 & 2 & 3 & 4 & 5 \\
\hline Profitability & & & & & \\
\hline Budget allocation & & & & & \\
\hline Market share & & & & & \\
\hline Quality of production & & & & & \\
\hline Delivery time & & & & & \\
\hline
\end{tabular}

\section{REFERENCES}

[1] Alexander, E. (2017). After rationality: Towards a contingency theory for planning. In Explorations in planning theory (pp. 45-64). Routledge.

[2] Awang, H., \& Iranmanesh, M. (2017). Determinants and outcomes of environmental practices in Malaysian construction projects. Journal of cleaner production, 156, 345-354.

[3] Begen, F. M., Barnett, J., Payne, R., Gowland, M. H., DunnGalvin, A., \& Lucas, J. S. (2018). Eating out with a food allergy in the UK: change in the eating out practices of consumers with food allergy following introduction of allergen information legislation. Clinical \& Experimental Allergy, 48(3), 317-324.

[4] Cai, P. (2017). Understanding China's Belt and Road Initiative.

[5] Cette, G., Lopez, J., \& Mairesse, J. (2018). Employment Protection Legislation Impacts on Capital and Skills Composition. Economie et Statistique, 503(1), 109-122.

[6] Chen, Y., Zhang, W., Yan, X., \& Jin, J. (2018). The life-cycle influence mechanism of the determinants of financing performance: an empirical study of a Chinese crowdfunding platform. Review of Managerial Science, $1-23$.

[7] Cicmil, S., Cooke-Davies, T., Crawford, L., \& Richardson,
K. (2017, April). Exploring the complexity of projects: Implications of complexity theory for project management practice. Project Management Institute.

[8] Creswell, J. W., \& Creswell, J. D. (2017). Research design: Qualitative, quantitative, and mixed methods approaches. Sage publications.

[9] Creswell, J. W., \& Poth, C. N. (2017). Qualitative inquiry and research design: Choosing among five approaches. Sage publications.

[10] Das, D., \& Ngacho, C. (2017). Critical success factors influencing the performance of development projects: An empirical study of Constituency Development Fund projects in Kenya. IIMB management review, 29(4), 276-293.

[11] De Leon, E. G., \& Pittock, J. (2017). Integrating climate change adaptation and climate-related disaster risk-reduction policy in developing countries: A case study in the Philippines. Climate and Development, 9(5), 471-478.

[12] Dvouletý, O. (2017). Effects of soft loans and credit guarantees on performance of supported firms: evidence from the Czech public programme START. Sustainability, 9(12), 2293.

[13] Eton, M., Mwosi, F., Mutesigensi, D., \& Ebong, C. D. (2017). Credit financing and performance of SMEs in Lira municipality, Uganda. Research Journal of Finance and Accounting, 8(8), 121-127.

[14] Gabler, S., \& Raykov, T. (2017). Evaluation of maximal reliability for unidimensional measuring instruments with 
correlated errors. Structural Equation Modeling: A Multidisciplinary Journal, 24(1), 104-111.

[15] García-Sánchez, E., García-Morales, V. J., \& Martín-Rojas, R. (2018). Analysis of the influence of the environment, stakeholder integration capability, absorptive capacity, and technological skills on organizational performance through corporate entrepreneurship. International Entrepreneurship and Management Journal, 14(2), 345-377.

[16] Garrido, L., Gomez, J., de los Ángeles Baeza, M., \& Vassallo, J. M. (2017). Is EU financial support enhancing the economic performance of PPP projects? An empirical analysis on the case of spanish road infrastructure. Transport Policy, 56, 19-28.

[17] Kirsch, F., \& Rühmkorf, R. (2017). Sovereign borrowing, financial assistance, and debt repudiation. Economic Theory, 64(4), 777-804.

[18] Lawrence, P. R., \& Lorsch, J. W. (1967). Differentiation and integration in complex organizations. Administrative science quarterly, 1-47.

[19] Maylor, H., \& Turner, N. (2017). Understand, reduce, respond: project complexity management theory and practice. International Journal of Operations \& Production Management, 37(8), 1076-1093.

[20] Miruri, R., \& Wanjohi, J. (2017). Determinants of performance of irrigation projects: Case of Nthawa irrigation project of Mbeere North Sub-county, Embu County, Kenya. International Academic Journal of Information Sciences and Project Management, 2(1), 447-463.

[21] Miruri, R., \& Wanjohi, J. (2017). Determinants of performance of irrigation projects: Case of Nthawa irrigation project of Mbeere North Sub-county, Embu County, Kenya. International Academic Journal of Information Sciences and Project Management, 2(1), 447-463.

[22] Mugenda, O. M., \& Mugenda, A. G.(2003). Research methods quantitative and qualitative approaches.

[23] Nawaz, T., \& Haniffa, R. (2017). Determinants of financial performance of Islamic banks: an intellectual capital perspective. Journal of Islamic Accounting and Business Research, 8(2), 130-142.

[24] Nguyen, L., \& Watanabe, T. (2017). The impact of project organizational culture on the performance of construction projects. Sustainability, 9(5), 781.

[25] Njeri, D. N., \& Were, S. (2017). Determinants of project performance in non-govermental organizations in kenya, a case study of hand in hand EASTERN AFRICA. International Journal of Project Management, 1(4), 61-79.

[26] Njeri, D. N., \& Were, S. (2017). Determinants of project performance in non-govermental organizations in kenya, a case study of hand in hand EASTERN AFRICA. International Journal of Project Management, 1(4), 61-79.

[27] Oyigbo, T. E., \& Ugwu, O. O. (2017). Appraisal of key performance indicators on road infrastructure financed by public-private

[28] Papke-Shields, K. E., \& Boyer-Wright, K. M. (2017).
Strategic planning characteristics applied to project management. International Journal of Project Management, 35(2), 169-179.

[29] Perkins, R., \& Repper, J. (2018). The independent review of mental health legislation: a real opportunity for change? Mental Health and Social Inclusion, 22(1), 1-5.

[30] Pettersson, R., Söderström, S., \& Nilsson, K. W. (2018). Diagnosing ADHD in adults: an examination of the discriminative validity of neuropsychological tests and diagnostic assessment instruments. Journal of attention disorders, 22(11), 1019-1031.

[31] Skorobogatova, O., \& Kuzmina-Merlino, I. (2017). Transport infrastructure development performance. Procedia Engineering, 178, 319-329.

[32] Song, H., Yu, K., \& Zhang, S. (2017). Green procurement, stakeholder satisfaction and operational performance. The International Journal of Logistics Management, 28(4), 1054-1077.

[33] Steinbach, A. L., Holcomb, T. R., Holmes Jr, R. M., Devers, C. E., \& Cannella Jr, A. A. (2017). Top management team incentive heterogeneity, strategic investment behavior, and performance: A contingency theory of incentive alignment. Strategic Management Journal, 38(8), 1701-1720.

[34] Vincent, G. M., Drawbridge, D., \& Davis, M. (2019). The validity of risk assessment instruments for transition-age youth. Journal of consulting and clinical psychology, 87(2), 171.

[35] Wang, Z., Li, H., \& Law, R. (2017). Determinants of tourism crowdfunding performance: an empirical study. Tourism analysis, 22(3), 323-336.

[36] Yin, R. K. (2017). Case study research and applications: Design and methods. Sage publications.

[37] Zahoor, H., Chan, A. P., Utama, W. P., Gao, R., \& Memon, S. A. (2017). Determinants of safety climate for building projects: SEM-based cross-validation study. Journal of construction engineering and management, 143(6), 05017005 .

[38] Zhang, W., Yan, X., \& Chen, Y. (2017). Configurational path to financing performance of crowdfunding projects using fuzzy set qualitative comparative analysis. Engineering Economics, 28(1), 25-34. 